\title{
Metaphysics and Dogmatism
}

\author{
Sergey F. Denisov ${ }^{\mathrm{a}}$ and Lubov V. Denisova ${ }^{\mathrm{b} *}$ \\ ${ }^{a}$ Omsk State Pedagogical University \\ 14 Tukhachevskogo embankment, Omsk, 644099, Russia \\ ${ }^{b}$ Omsk Academy of the MIF of Russia \\ 7 Komarova Av., Omsk, 644092, Russia
}

Received 24.01.2015, received in revised form 14.02.2015, accepted 20.05.2015

The present article provides a brief characteristic of the three concepts of metaphysics that emerged during the history of philosophy. The first one, the concept by Descartes, indicates metaphysics as the fundament for philosophy; the second one, the concept by Hegel, understands metaphysics as a rational style of thinking. Aristotle claims that the initial concept contains the idea of the extrasensory reality which is the object of metaphysics as a division or a type of philosophy. The article substantiates the connection of metaphysics with the agent's confidence of the objectiveness of cognition, or dogmatism. It states the principal antagonism of dogmatism and skepticism as epistemological mindsets. It arrives at the conclusion that dogmatism is an epistemological and an ontological phenomenon which manifests itself in the agent's confidence of objective learning of the world, of the creative power of mind and its ability of absolute value construction. The presented characteristic of dogmatism points at its underlying role in both cognitive activity and in the establishment of different types of world outlook.

Keywords: metaphysics, dogmatism, extrasensory reality, philosophy, skepticism, epistemological mindset.

Research area: philosophy.

Since the times of R. Descartes metaphysics has been considered to be the fundament for philosophy [Descartes R. 1989. P. 309]. Martin Heidegger, who had been paying great attention to the search for the answer to the question on what metaphysics is, finally arrived at the following conclusion: the object of metaphysics is being: "it deals with beings as beings. In this manner, metaphysics always represents beings as such in their totality; it deals with the beingness of beings" [Heidegger M. 1993. P.34]. The tradition to refer to the major, basic problems of philosophy as metaphysical was supported by both Western and Russian existentialists [See Abbagnano N. 1998; Berdiaev N.A. 1995]. In modern Russian research both the term and the theme of metaphysics itself is used as a marker for basic knowledge or the main ideas of any branch [Bachinin V.A., 2001; Hildebrand D., 2000; Terebikhin N., 2004].

In Russian philosophy of the Soviet period metaphysics was understood within the framework of ideas of Engels. Understanding of metaphysics was limited to the reasonable style

(C) Siberian Federal University. All rights reserved

* Corresponding author E-mail address: decanka@mail.ru 
of thinking opposed to dialectics. However, the original source of this idea is the philosophy of Hegel who, assuming the Medieval scholastics, wrote: "It is however only in reference to the history of philosophy that this Metaphysic can be said to belong to the past: the thing is always and at all places to be found, as the view which the abstract understanding takes of the objects of reason" [Hegel, P. 134]. It was this meaning of metaphysics that was expanded in Marxist philosophy due to the famous works of F. Engels "Dialectics of Nature" and "Anti-Dühring". They opposed metaphysics and metaphysical style of thinking to dialectics. Just like Hegel, Engels referred to metaphysics as to a matter of reason, considering the metaphysical way of thinking to become "one-sided, restricted, abstract, lost in insoluble contradictions" [Engels F., 1961]. After the works by Hegel and Engels, in Marxist philosophy metaphysics became a synonym of anti-dialectics, and later a universal tag to indicate any weaknesses of the criticized theories [Lenin Reflection Theory, 1981].

The rejection and abrupt criticism of reasonable metaphysics brought certain confusion into the established terminology. Consequently, in the history of philosophy the following customs of term use have been developed.

The first understanding of metaphysics can be called after Descartes. Here metaphysics is understood as the core, the central and the basic part of philosophy, the fundament of it. This meaning is emphasized by both Existentialists and neo-Thomists. The second meaning dates back to Hegel and Engels, where metaphysics acted as the antipode of dialectic thinking. However, metaphysics owes its most ancient and original meaning to Aristotle and his students [See Motroshilova N., 1964; Lobkovich N., 1995].

The term of metaphysics was first mentioned in the $1^{\text {st }}$ century B.C., when its meaning was formed under the influence of two traditions.
According to the first of them, the meaning of the term originated from the treatise by Aristotle that spoke of the "first philosophy" or the "divine science".

A librarian from Alexandria, Andronicus of Rhodes, the eleventh scholarch of Peripatetic school who created the first full editions of all the works by its founder, arranging the works by Aristotle in the order they are still presented in the modern editions: starting from logics, natural philosophy to ethics, politics and rhetoric. In the series of fourteen books "Metaphysics" followed another one, "Physics", and its title, "ta biblia ta meta ta physika" is literally translated as "the books that come after the [books on] physics". Before Andronicus of Rhodes the term "metaphysics" in relation to the treatise by Aristotle had never been used, which is proved by the famous work by Diogenes Laertius, who mentioned the work of the first philosophy by Aristotle without using its present title.

The second tradition is also connected to the interpretation of works by Aristotle. The ones standing at the origins of this tradition are, obviously, Alexander of Aphrodisias and Neo-Platonist Asclepius. They suggested that metaphysics owed its existence exceptionally to the fact that the disputable texts were dedicated to the divine reality, consequently, separated from matter. The tradition is based on the polysemy of the Greek word "meta" itself, which means, "beyond, later, after". That is why "Metaphysics" by Aristotle was understood as the "book narrating of what lies beyond physics". This tradition was developed in the Medieval period, brightly incarnated in Thomism. The new times established the tradition in the whole scholastics and in the times of Kant and Hegel metaphysics became the symbol of the scholastic, or, as it has been mentioned above, reasonable thinking.

However, it is possible that understanding of "Metaphysics" of something following physics 
was a mere coincidence. But one should notice that the word "metaphysics" itself bears a deep meaning which finds its reflection in the semantics of the term itself. In the times of Aristotle and in the medieval times the "physicists" mostly relied on their sensation, which caused the association of physics in the philosophic-epistemological dimension with sensory perception. Correspondingly, physics or sensory perception is followed by conceptual thinking. In other words, the concept of metaphysics originally states the indication not of the sensory, but of the intellective, extrasensory reality, of the product of abstract, underlying thinking, which are the categories presented in the treatise by Aristotle. Such coincidence cannot be ignored. Therefore, we may now speak of the original, or of the third meaning of the term, which refers to metaphysics as to the science of the extrasensory.

Consequently, the subject matter of metaphysics is the extrasensory world, different from the sensory world given in sensation. The extrasensory world includes a series of ideal objects, concepts, moral principles, ideals and supreme purposes of human existence which principally cannot be perceived by means of sensation. It is only a singular utterance the existence whereof the latter is able to prove, while the objects of extrasensory world consist of universal concepts and ideas lying beyond sensation. In this way, the extrasensory world is off-the-limits for human contemplation, if, of course, by the limit we understand sensation itself. Such off-the-limits contemplations can be neither confirmed nor refuted by means of sensation [Kant I., 1966. P. 183].

As, being detached from the terrestrial basis of sensation, thinking goes beyond the limits, the arising of the question of objectivity of such sphere is inevitable. There is little chance that anyone would guarantee that their reason, leaving the grounds of sensation, may avoid illusions.
Perhaps, everything created by the reason is nothing but chimaeras existing nowhere but in our imagination. It should seem that this problem must paralyze the activity of mind at least at the initial stages of development of metaphysics as a science of the extrasensory. But the reason overcomes this state due to dogmatism, or the confidence of the person of the objectivity of the extrasensory world, making metaphysics possible.

Modern secular culture usually reads negative sense in the concept of dogmatism. Once, there was a depreciating description of dogmatism worded in the treatise by I. Kant who considered his main task to relieve the science from the "old worm-eaten dogmatism" [Kant I., 1965. P. 74]. In Russian philosophy of the Soviet period dogmatism was categorically understood as an unserious, shallow, superficial style of thinking [Dogmatism, 1983; Sitkovsky E., 1962].

A different understanding of dogmatism arises at the consideration of the term within the religious doctrine context [See Kanakov D.V., 2010]. Dogmatism cannot be understood correctly without consideration of its etymology which goes back to the Greek term of "dogma" which is literally translated as "anything declared right". Cicero used the word dogma to refer to such doctrines which, being commonly known, had the significance of the undeniable truth. In the ancient times the word "dogma" also referred to the decrees and resolutions of the authorities asking absolute obedience.

In philosophy, the abstract theorems, as well as ideals, are not subject to substantiations by means of sensation; their verity does not evoke any doubt due to their simplicity or is simply taken on trust. Thus, Aristotle used the word "dogma" to refer to the general conviction of the philosophers that "nothing comes from nothing". It is known that the Epicureans and the Stoics believed that a wise man needed to have dogmas, 
i.e. some theorems and ideals to follow and reach the right and truthful way of life.

According to Sextus Empiricus, the classification of the main philosophic trends may be based on the attitude of philosophers to the truth. Sextus Empiricus calls the first ones the Dogmatists, who claim that they have found the truth; among them, he lists Aristotle, Epicurus and the Stoics. The second ones suggest that the truth cannot be perceived or reproduced in any way: it is a group of Academists headed by Carneades, Clitomachus and others. The third ones composing the group of Skeptics are still engaged with the search for the truth. Proceeding from this, writes Sextus Empiticus, it is correct to admit that there are three basic genera of philosophy: dogmatic, academic and skeptic [Sextus Empiricus, 1976. P. 207].

It is remarkable that in the ancient epoch one of the basic objects of criticism for the Skeptics was the philosophy of the Stoics, which claimed more than cognoscibility of the world, but also naturalness of reason, as well as the necessity for human to rely on the rational form of nature. In order to substantiate the rationality of human behavior the Stoics used to include some rational power into the structure of nature, believing it to be controlling the irrational nature, regulating and leading it to the supreme purposes. According to the Stoics, all the endless diversity of the things existing in the world are compelled by cosmic reason to the main objective, which is the victory of rational nature over irrational, of the superior reason over the inferior. The main idea of Stoic anthropology was the idea of impartial attitude to the world. Impartiality in human behavior was understood as the expression of rational nature domination over the irrational. Therefore, passion was interpreted as irrational, contradicting the rational nature, not nature in general. This idea served as the basis for the Stoic formula of freedom as the conscious need and submission to it. One should also notice that by need the Stoics understood rational nature as such. Consequently, freedom could be also defined as submission of a human to the rational nature. The misunderstanding of this central Stoic idea often leads researchers to wrong conclusions [See, for example, Chanyshev A.N., 1991].

According to I. Kant, Skepticism could be wise and useful for metaphysics if it reached the initial point not to stop at it, but to keep going forward. Skepticism has not only been stacked against metaphysical dogmatism; it has always strived for casting doubt even on sensation itself [Kant I., 1966].

The whole history of skepticism says that it was originally anti-metaphysical and stacked against dogmatism, i.e. it was ultimately aimed at the destruction of the fundaments of metaphysics, casting doubt on the ability of reason to cognize the underlying causes of things. Skepticism judges from what the reason can assume about the things given to the person in his sensation only. In other words, reason is limited with the framework of experience, while the epistemological capacity of the latter is known to be strictly limited. According to D. Hume, reason is not capable of cognizing the cause and consequences; these categories are nothing but a phenomenon of our psychological confidence, i.e. subjective in their essence. Probably the deepest causes and principles that we shall ever discover in nature are these: elasticity, gravity, cohesion of parts and communication of motion by impact. "We shall be lucky if by careful work we can explain particular phenomena in terms of these four, or something close to them" [Hume D., 1966. P. 33]. The incapability of reason to cognize the cause and sequence relations leads metaphysics to impossibility as a science of the extrasensory. I. Kant noticed that "The acute man was, however, looking only to the negative benefit that curbing 
the excessive claims of speculative reason would have, in completely abolishing so many endless and continual conflicts that perplex the human species; he meanwhile lost sight of the positive harm that results if reason is deprived of the most important vistas, from which alone it can stake out for the will the highest goal of all the will's endeavors" [Kant I., 1965. P.72].

So, opposing dogmatism to skepticism, one may outline the following generic features of metaphysical dogmatism.

First of all, dogmatism relies on the confidence in the achievement of the truth. Any cognition of being, underlying foundations of the world, any construction of the saintly life ideals necessarily suggests the presence of such confidence in the success, in the real achievement of the truth. Skepticism, on the opposite, is aimed at the denial of such a mindset [See also Nikolaev E.A., 2009]. From the psychologicalepistemological point of view dogmatism is characterized with optimism, while skepticism with pessimism.

Secondly, the psychological confidence of a scholar calling himself dogmatic in the cognition of the truth relies, first of all, on the confidence in the creative power of mind and thinking. The position of metaphysical dogmatism assumes that human mind is not only capable of objective cognition of the world, but also of the functioning similarly to the surrounding nature, following the laws independent from the subjective desires of both the person and the humankind as a whole. This dogmatic confidence found its incarnation, on one hand, in the idea of equality of being and thinking, and on the other hand, in the idea of adequate reflection of the objective reality in the human consciousness. From this point of view dogmatism can be characterized as objectivism, while skepticism - as subjectivism.

Thirdly, the dogmatic confidence in the creative power of mind manifests itself in the idea of irrational nature and the rational need a person should orient to. Skepticism with its antidogmatic mindsets aims at, first of all, the denial of reason, strives to substantiate the need for a human to surrender to irrational nature.

To conclude, we may also add that skepticism is not the only thing dogmatism is opposed to; it is also opposite to sophistics. This opposition is manifested in between "absolute relative". A dogmatic scholar insists on the possibility of constructing absolute knowledge and absolute values, which is significant for the substantiation of epistemological optimism and moral values.

Therefore, dogmatism is an epistemological and ontological phenomenon which manifests itself in the confidence of a person in the objective cognition of the world, in the creative power of mind and its ability to construct absolute values. This dogmatism presents what I. Kant used to call "the natural inclination of man to metaphysics". Even though metaphysics proved to be incapable of substantiating the objectivity of thinking, it is saturated with the confidence in the existence of objective laws of thinking, in the laws for development of mind similar to those of the laws regulating the human world itself. Obviously, many people are aware of the dogmatic character of metaphysics, as human knowledge is limited and the surrounding reality is inexhaustible; for this reason, searching for the supreme sense of nature or "the world order", as Fichte used to say, a metaphysicist has to rely on nothing but faith. Human knowledge covering only a minor part of the whole reality is not capable of describing this "world order" in the genuinely scientific way leading to reliable results. The only thing it has is the faith in the greater good, forming the fundament for any certain reality [Lotze R.H., 1971. P. 637].

The significance of dogmatism in the theory of cognition is enormous. It is 
dogmatism that makes metaphysics possible. It is due to dogmatism a person leaves its sensory world and aspires to get beyond it, to reach the extrasensory reality, unaware of having flung himself to the mercy of metaphysics. Dogmatism as epistemological confidence of person of the objectivity and absoluteness of the extrasensory world does not remain unchanged; just like everything in this world, it is subject to development. At the first stages of its formation dogmatism generates the mythological reality, then the religious reality until finally it becomes the base for the epistemological and logical argumentation leading to the development of philosophy. A myth is deprived of any epistemological reasons, and the confidence in the objectivity and absoluteness of the extrasensory world is blindly supported by customs and traditions: in religion confidence is predominantly unproved, relied on the psychological confidence in better life and salvation; in philosophy, metaphysical dogmatism finds its development in science and the world outlooks it generates.

\section{References}

1. Abbangano N. Struktura ekzistentsii. Vvedenie v ekzistentsializm. Pozitivnyy ekzistentsializm $i$ drugie raboty [Structure Of Existence. Introduction To Existentialism. Positive Existentialism And Other Works]. Saint Petersburg, 1998. P. 39.

2. Bachinin V.A. Dostoevskiy: metafizika prestupleniia: (khudozhestvennaia fenomenologiia russkogo postmoderna) [Dostoyevsky: The Metaphysics Of Crime: Literary Phenomenology Of Russian Post-Modernism]. Saint Petersburg University? 2001.

3. Berdiaev N.A. Opyteskhatologicheskoymetafiziki. Tvorchestvoiob'ektivatsiia [Eschatological Metaphysics Experience. Creativity And Objectification] // Tsarstvo dukha i tsarstvo kesaria. Moscow, 1995. P. 164.

4. Hegel. Entsiklopediia filosofskikh nauk [Encyclopaedia Of The Philosophical Sciences]. In 3 volumes. Moscow, 1975. Vol. 1. P. 119.

5. Hildebrand, von D. Metafizika kommunikatsii. Issledovaniie suschnosti i tsennosti obschestvennykh otnosheniy [Metaphysics Of Community. Research Of Essence And Values Of Social Relations] // Dietrich von Hildebrand. -[A.I. Smirnov (translated from German)] // Saint Petersburg: Aleteyia: TO Stypeni, 2000.

6. Descartes R. Pervonachala filosofii [Principles Of Philosophy] // Collection. In 2 volumes. Moscow, 1989. Vol. 1. P. 309.

7. Dogmatizm [Dogmatism] // Filosofskiy entsiklopedichskiy slovar'. Moscow, 1983. P. 173.

8. Kanakov D.V. Fenomen religioznogo dogmatizma. K postanovke problemy [Religious Dogmatism Phenomenon. Problem Statement] // Voprosy religii i religiovedeniia. Vol. 2. Issledovaniia. Saint Petersburg-Moscow, 2010. Book 1 (I). P. 290-296.

9. Kant I. Kritika chistogo razuma [Critique Of Pure Reason] // Collection in 6 volumes. Moscow, 1965. Vol. 4. P. 118-119.

10. Kant I. O voprose, predlozhennom na premiiu Korolevskoy berlinskoy akademiey nauk v 1791 g.: Kakie deystvitel'nye uspekhi sdelala metafizika v Germanii so vremeni Leybnitsa i Vol'fa? [To The Issue Nominated For The Award Of Royal Berlin Academy Of Science In 1791: What Actual Success Has Metaphysics Reached Since The Times Of Leibnitz And Wolf?] // Kant I. Collection in 6 volumes. Moscow, 1965. Vol. 6. P. 183. 
11. Kant I. Prolegomeny ko vsiakoy buduschey metafizike, moguschey poiavit'stia kak nauka [Prolegomena To Any Future Metaphysics That Will Be Able to Come Forward as Science. 1783] Kant I. Collection in 6 volumes. Moscow, 1965. Vol. 4. Part 1. P. 72.

12. Leninskaia teoriia otrazheniia v svete razvitiia nauki i praktiki [Lenin's Theory Of Reflection In The Context Of Development Of Science And Practice]. In 2 volumes. Sofia, 1981. Vol. 1. P. 18.

13. Lobkovich N. Ot substantsii k reflexii [From Substance To Reflection] // Voprosy filosofii. 1995. No. 1.

14. Lotze R.H. Osnovaniia metafiziki [Basics Of Metaphysics] // Antologiia mirovoy filosofii. In 4 volumes. Moscow, 1971. Vol. 3. P. 637.

15. Motroshilova N., Ogurtsov A., Turovskiy M., Potemkin A. Metafizika [Metaphysics] // Encyclopaedia of Philosophy in 5 volumes. Moscow, 1964. Vol. 3. P. 402.

16. Nikolaev E.A. Skeptsitsiam i dogmatism kak metodologicheskie ustanovki [Skepticism And Dogmatism As Methodological Mindsets] // Chelyabinsk State University Newsletter. 2009. No. 42. P. 118-128.

17. Sextus Empiricus. Tri knigi Pirronovykh polozheniy [Outlines Of Pyrrhonism] // Collection of works in 2 volumes. Moscow, 1976. Vol. 2. P. 207.

18. Sitkovskiy E. Dogmatizm [Dogmatism] // Filosofskaya entsiklopediia. Moscow, 1962. Vol. 2. P. 37.

19. Terebikhin N. Metafizika Severa [The Metaphysics Of The North]. Arkhangelsk: Pomor University, 2004.

20. Heidegger M. Vvedenie k "Chto takoe metafizika?" [Introduction To What Is Metaphysics?] // Heidegger M. Time And Being: Articles And Speeches. Moscow, 1993. P. 34.

21. Chanyshev A.N. Kurs lektsiy po drevney i srednevekovoy filosofii [Course Of Lectures On Ancient And Medieval Philosophy]. Moscow, 1991. P. 140.

22. Hume D. Issledovanie o chelovecheskom poznanii [An Investigation Into Human Cognition] // Collection of works in 2 volumes. Vol. 2. Moscow, 1966. P. 36.

23. Engels F. Anti-Diuring. Dialektika prirody [Anti-Dühring. Dialectics Of Nature] // Marx K., Engels F. $2^{\text {nd }}$ edition. Moscow, 1961. T. 20. 


\section{Метафизика и догматизм}

С.Ф. Денисов ${ }^{\mathbf{a}}$, Л.В. Денисова ${ }^{\boldsymbol{\sigma}}$

${ }^{a}$ Омский государственный педагогический университет Россия, 644099, Омск, наб. Тухачевского, 14

${ }^{6}$ Омская академия МВД России Россия, 644092, г. Омск, пр. Комарова, 7

В статье дана краткая характеристика трех возникших в истории философии смыслов метафизики. Первый - декартовский - указывает на метафизику как фундамент философии, второй - гегелевский - является пониманием метафизики как рассудочного стиля мышления. Аристотелевский - первоначальный смысл содержит представление о свехчувственной реальности, которая и становится объектом метафизики как раздела или вида философии. В статье обосновывается связь метафизики с уверенностью субъекта в объективности познания - догматизмом. Утверждается принципиальный антагонизм догматизма и скептицизма как гносеологических установок. Делается вывод о том, что догматизм представляет собой гносеологическое и онтологическое явление, которое проявляется в уверенности субъекта в объективном познании мира, в творческой мощии разума и его способности конструировать абсолютные ценности. Представленная характеристика догматизма содержит указание на его важнейшую роль как в познавательной деятельности, так и в становлении различных типов мировоззрения.

Ключевые слова: метафизика, догматизм, сверхчувственная реальность, философия, скептицизм, гносеологическая установка.

Научная спеииальность: 09.00.00 - философские науки. 